\title{
The Handicraft Teachers' Habits in Choosing and Using Courses of Continuing Education
}

\author{
Ene Lind $\mathrm{PhD}$ \\ Tallinn University, Estonia \\ enelind@tlu.ee
}

\begin{abstract}
Becoming a professional teacher is an everlasting process. Its aim is to achieve a mastery of teaching and the ability to see the links of educational work that a beginner teacher doesn't notice. Teachers' development is supported by continuous training. The aim of current study was to find out the habits of handicraft teachers in choosing and using courses of continuing education. The current study used questionnaires and interviews with teachers. The results of our research show that handicraft teachers engage in further training, but it is mostly connected with developing their practical skills rather than acquire didactic knowledge. The reason for that can be seen from two aspects. Firstly, handicraft for handicraft teachers is both work and a hobby. They want to combine possible training courses with their personal interests. Secondly, older generation of teachers are used to participate in practical vocational courses.
\end{abstract}

Keywords: school education, handicraft teachers, teacher's professionalism, continuing education.

\section{Introduction}

The profession of a teacher is complicated, interesting and responsible. Skill of a pedagogue determines the basic mutual relationship between the student and the material: how the students understand the subject, and how the taught subject helps to develop a dignified personality (Phelan, Locke-Davidson, Cao, 1992, Mullock, 2003, Malik, Bashir, 2015). Today's teachers must be innovative to engage and inspire 21st century learners (Lifelong Learning is..., 2015). According to the Estonian Teacher Education Strategy, a competent and effective teacher is able to create a democratic and safe classroom environment (The Estonian Teacher..., 2012).

Being a teacher means teaching, responsibility for children and their studies and development, which is born in the communication between the teacher and the student (Sarv, 2008; Teacher professionalism, 2012). Also, being a teacher is tightly connected to education, taking place in the relations with the student, where personal behaviour of the teacher has major role (Brownell et al., 2006; Loogma, Keskula, Roospold, 2010; Lofstrom et al., 2010; Wilkins, 2014). Creating a sense of self as a professional is an important stage in developing an effective teacher (Thomas, Beauchamp, 2007).

Changes in education and society set new requirements to the profession of a teacher. In addition to the communication of basic knowledge, it is constantly more expected from teachers that they would help young people to acquire the basic skills for becoming completely independent learners, instead of just learning simple information. Use of cooperation-based and more constructive methods is increasingly demanded from teachers, and they are expected to act rather as assistants and guides of learning activities than persons sharing knowledge from authoritative position (Improving the quality..., 2007). A professional teacher is characterized by up-to-date knowledge of the subject and of teaching methods, readiness to do research. A professional teacher applies versatile teaching methods, is creative and consistent in one's teaching. Another indicator of professionality is the willingness to be open to new information that enhances his/her knowledge and practical experience with new insights from different fields (Beishuizen et al., 2001; Arnon, Reichel, 2007).

In the field of teaching and teacher education, the focus is on teacher thinking and reflection. For a teacher, this means continuous taking of opinions and making decisions. One particular point of view is the question how teachers move in their thinking from the descriptive to the normative (Kansanen, 1993). Thereby it is important, what is the background of the teacher, and what knowledge they use for thinking and decision-making (Kansanen, 1995). Similarly, to other contemporary professions, also teachers are obliged to broaden the limits of their professional knowledge through self-analysis, research and constant systematic professional self-improvement from the beginning to the end of their career, in order to raise their level and competency. 


\section{The role of continuing education in a teacher's professional development}

Possible forms of continuing education for teachers are following (Creating Effective Teaching..., 2009):

- courses or workshops;

- conferences or seminars related to education;

- qualification programmes;

- observation visits to other schools;

- participation in (subject-related) professional network;

- participation in project work;

- observation and instruction of others;

- reading professional literature.

Although continuing education for teachers is nationally regulated and specified in the law, it is also possible to choose less-developing and small-scale training courses. Teachers are very independent to determine their objectives and methods, and nothing ensures or controls the correctness of their operation. Therefore, the personality of a teacher has major importance; they are responsible for the development of themselves and their professional skills. Their choices have decisive meaning. A teacher is responsible, if their life and pedagogical methods are good or bad, valuable or of no value, thorough or superficial.

Handicraft teachers' contentment with their professional preparation is important, because availability of knowledge makes it easier to pass necessary new ideas to the students and to create a suitable study environment (Gagne, Driscoll, 1988). Of course, on the basic level of teacher education it is not possible to acquire knowledge and skills needed for the entire career (Improving the quality..., 2007), but based on the professional preparation, a teacher can assess their knowledge and competencies, their sufficiency, and the need for self-improvement.

When planning professional development, it is important to draw summaries, to reflect one's own work - which are the current possibilities for development, which activities could be continued, which should be discharged, and to find problematic spots for further handling (Goe, Biggers, Croft, 2012). Professional self-improvement does not mean only participation in lectures and courses, but acquisition of principal learning habits. The newer knowledge is practised, the stronger these new habits will become (Fullan, 2015). Teacher should have clear understanding of the objectives of their activities, planning, necessary tools, processes, assessment and feedback (Beishuizen et al., 2001). In teacher training and real school situation people tend to concentrate mainly on practical knowledge and skills related to teaching of a subject, leaving the educational values related to teaching to the background. Knowledge and skill of a teacher do not develop only during practical work as a teacher, although such opinion is quite common among the public as well as teachers themselves. Naturally, in the development of these skills a teacher should be supported by relevant training, i.e. the skills of a teacher to obtain and handle knowledge themselves shall be in continuous development process.

For a teacher, continuing education means new knowledge and conceptions through centrally organised trainings. Well-functioning continuing education taking account of the needs of teachers is useful for teachers as well as the state. It is in the interest of the state that school teachers would be professionals of their speciality, who can adapt to changing situations and update continuously their professional skills. Participation in continuing education means also security in addition to replenishment of knowledge participation in a system - (continuing education) enables to preserve and develop their qualification.

The survey „High-Quality Professional Development for All Teachers” (Archibald et al., 2011), which results were published in 2011, highlighted five points determining and specifying professional development of a teacher, including use of continuing education:

- standards and prescriptions specified by the state and the school;

- concentration on the most important - development of teaching strategies for daily work;

- possibilities to study new teaching strategies;

- cooperation with other teachers;

- feedback from work.

The quality of teachers and their activity in mutual relationship with the achievements of students is a major aspect in school, which has impact on the results of the students (Montalvo, Mansfield, Miller, 2007). Also, there is a positive relationship between continuing education of teachers and the 
achievements of students. Teacher education has improved the results of the children more than e.g. minimising the size of class or increasing the number of school lessons. If teachers want to change something in students, they should first look, if there is something in themselves, which should be changed. (Improving the quality..., 2007).

In Estonia, a popular method of self-improvement is participation in continuing education, which has been studied more thoroughly in this paper. The aim of current study was to find out the habits of Estonian handicraft teachers in choosing and using courses of continuing education. Specific questions were the frequency of participation of handicraft teachers in courses of continuing education, the content of more popular courses, and possibilities to participate in continuing education.

\section{Methodology}

The combined research design was used in the research. The main research method was quantitative review research, more specifically web-based questionnaires, as this method requires less time, and is secure and anonymous.

A questionnaire was sent on random basis to 150 Estonian handicraft teachers. The questionnaire included 25 questions, of which 24 were obligatory. The last question was voluntary and intended for provision of own opinion of the topic. The drafted questions were multiple choice questions, enabling to compare the answers.

Furthermore, structured individual interview was used for specifying the collected data, which was conducted in the same period with questionnaires. A tool used to assist the interview was the same questionnaire, where the form and sequence of questions and options were specified.

Three teachers were interviewed, who were chosen on random basis with the condition that they had to possess at least ten years of work experience in different regions of Estonia. Two of the selected teachers were working in different major cities and one in a school located in a small town.

The opinions of interviewed teachers were added into the paper as comments, proposals and recommendations. For the results and analysis of interviews, the teachers were provided a code based on the sequence of conducted interviews. Answers of the first interviewed teacher were marked with the code „T1” (Teacher 1), second „T2“and third „T3“. Teachers T1 and T2 worked in a city school, T3 in a smaller school located in a small town.

Answers were received from 53 teachers. Most respondents were 41-50 years of age (43\%), the second group included teachers with 51-60 years of age (27\%), followed by 31-40 years of age (18\%) and 20-30 years of age (10\%). Two percent of the respondents were over 60 years of age.

Most teachers had higher education in their speciality. Seventeen percent of the respondents had up to five years working experience, $11 \%$ had worked 5-10 years, $37 \%$ of the respondents $10-15$ years, $25 \%$ had worked as a teacher for 15-20 years, and $10 \%$ more than 20 years. In Estonia, the staff of teacher is generally becoming older - average age of teachers is 44 years and average working experience 18 years (Uldhariduse pedagoogide kohta..., 2017).

Fifty seven percent of the respondents were working in city schools, $37 \%$ in small towns and $6 \%$ of the respondents in rural schools.

\section{Results and Discussion}

Teachers' vocational choice and professional preparation. First, we wanted to know, what had motivated the teachers to choose this profession and speciality. As the choice of profession is influenced by internal as well as external factors, the following options were offered to the teachers for answering:

- wish to teach national culture -2 teachers;

- wish to work with young people -2 teachers;

- to get good salary - 1 teacher;

- traditional profession in the family - 0 answers;

- wish to teach and help young people to see the outputs of various creative activities -15 teachers;

- wish to join work and hobby -33 teachers. 
It can be seen that the main motivator for handicraft teachers was the intention to join work and hobby (62\% of the respondents). Also, many teachers wanted to teach and help young people to see the outputs of various creative activities ( $29 \%)$. Other offered options were clearly less popular.

Similarities can be seen when comparing the results of our research with the research conducted by E. Veeber (2009), which analysed the reasons for being a handicraft and home economics teacher. Also, in 2009 the main reason for being a teacher was that being a handicraft teacher means work for a pedagogue, which is also a hobby. It was also noted in the mentioned research that being a handicraft teacher means teaching and passing (sharing) knowledge and skills, being in a youthful working environment. Thus, the motivation of Estonian handicraft teachers has not changed in the course of years but has remained the same.

A major aspect indicating job satisfaction is assessment of professional preparation (of a handicraft teacher). Two thirds of the respondents considered the professional preparation sufficient, while others found that it could be better. The interviewed teacher, who had critical attitude to the preparation (T1), was asked to specify the shortages. The main problem specified by the teacher was the fact that during studies many samples had been made in various techniques, which could not be used actually in school. This provides two topics for discussion:

a) preparation has been thorough, but the skill to use it is not sufficient;

b) preparation methodology has not been suitable for the conduction of actual study process.

The participation of training courses. As the requirement for participation in continuing education is specified in the law, the teachers were asked to assess, if they consider participation in continuing education important for self-development or for showing to the management of the school. In this aspect, the teachers having participated in the research had clear opinion: all considered participation in continuing education important for their development. The interviewed teachers explained such choice as follows: they mainly wanted to study new and extracurricular techniques, to communicate with colleagues and to exchange information about problems occurring in the lessons. As for the answers, a somewhat alarming fact is the wish to study extracurricular techniques, which shows that teachers do not want to participate in continuing education for raising their professionalism, but for improving the skills needed for hobby.

On the other hand, the term "extracurricular topic" may refer to the former years-long habit of teachers related to work with the curriculum. The conception of the Estonian national curriculum for basic and upper secondary schools implemented in year 2002 differed substantially from earlier curricula. The centralized Lehrplan-type curriculum that concentrates on subject and content by indicating precise tasks was replaced by the student-centred curriculum that is more indicative, giving general guidelines. The same principle is continued in the new curriculum for basic schools, certified in 2011 and amended in 2014 (National curriculum for..., 2014). As $35 \%$ of the teachers participating in the research have worked as a teacher already with the old content-based curriculum, it may be confusing and difficult to get used to the new concept. At the same time, this shows the need for curriculum-based continuing education.

Analysis showed rather high frequency of participation of teachers in continuing education courses: in recent five years, $68 \%$ of the teachers had participated in the courses. Only one teacher noted that she had not participated in continuing education courses in recent years. When the interviewed teachers were asked to explain the frequency of participation in continuing education courses, an interesting fact was found. A repeated explanation for participation in professional training course was "cheerful company, with whom it is fun to spend time". This shows that the community of handicraft teachers forms a solid circle supporting each other, who gather for regular communication; this could overshadow even the wish for professional self-improvement. However, communication with colleagues and exchange of experiences is a form of continuing education.

In order to find out, which is the duration of training courses preferred by the teachers, the respondents were asked to choose between two options: short-term (one-day) or longer (several modules lasting several days) courses. The respondents preferred rather one-day (64\%) than longer (36\%) training courses. The popularity of one-day courses was explained by the fact that usually these do not include home tasks, which are generally included in the programme of the courses lasting several days. Thus, short-term training courses may mean rather the wish to spend time in pleasant company and to deal with pleasant activity/hobby. Teachers found that the best trainers are practising teachers themselves, 
because usually "a teacher of regular school knows, how to conduct exciting and feasible work with students with available possibilities". A training course lasting several days means involvement of a professional trainer and possibility for in-depth handling of the topic, which was also noted by the interviewed teachers. Three options were offered to the question "What do pedagogues understand by educational training":

- theoretical training courses (lectures);

- courses mixing theory with practice;

- training courses basing mainly on practical work.

Teachers preferred training courses, where theory was combined with practice $(70 \%$ of the respondents). The interviewed teachers (T1 and T3) explained this as follows: practical work combined with theory helps to acquire better the studied material. However, also other options were mentioned as preferences. Twenty five percent of the respondents had the opinion that educational training is training basing mainly on practical work. This option was also supported by one interviewed teacher (T2), who said that through practical work a teacher learns more new knowledge/skills than by listening to the theory. Among the respondents $(6 \%)$ there were also those, who found that theoretical training courses (lectures) were most educational. The general notion was that the more different new activities/technologies are acquired, the more educated the teacher becomes. According to P.C. Meijer, it should be characteristic to the practical knowledge of a teacher that it includes researchbased/theoretical knowledge, as well as special knowledge from the practice of the teachers themselves, and comprehension, how these two are related to each other (Meijer, 2013). However, it cannot be said that this would be only the interest of handicraft teachers in self-improvement through mainly professional knowledge.

Importance of practical professional skills for the teachers is also supported by the fact that $82 \%$ of the participants answered that their latest training course had been a professional practical course of continuing education. Twelve percent of the respondents had participated in a continuing education course of educational science, and $6 \%$ of the respondents had participated in a training course related to career and counselling or general education.

Teachers consider continuing education necessary for themselves, but training courses are not always voluntary. Sometimes the management of the school orders a course or sends the teacher to a specific course. Therefore, it is difficult to assess in the answers described above, how much these non-specialityrelated themes actually interested the teachers. When comparing preferences of teachers to their latest participated courses shown in Table 1, the correlation of reality with wishes becomes clear.

Table 1

Training courses for teachers

\begin{tabular}{|l|c|c|}
\hline \multicolumn{1}{|c|}{ Training courses } & Preferences & Latest \\
\hline Theoretical training courses (lectures) & $6 \%$ & $23 \%$ \\
\hline Courses mixing theory with practice & $70 \%$ & $6 \%$ \\
\hline Courses basing on practical work & $25 \%$ & $82 \%$ \\
\hline
\end{tabular}

Teachers do not directly criticise educational (generally theory-based) training courses. One interviewed teacher (T1) notes that there are undoubtedly good training courses, just they have not happened to participate in such. Teacher T3 clearly prefers professional training courses: "I have studied already enough dry theory". One respondent noted: "I care more of self-education on horizontal level (from being a human to studying of any culture/object/field) than on vertical (studying specific handicraft techniques)".

The pedagogues having participated in the research had common opinion that participation in professional training courses helps teachers to fulfil better the curriculum. As much as $93 \%$ of the respondents shared this opinion. One interviewed teacher (T3) specified: "Otherwise there would not be the knowledge to teach". It can be concluded from here that in opinion of teachers, new knowledge/techniques are needed for the fulfilment of curriculum. However, as teachers already noted that they mainly expect extracurricular techniques from training courses, there is clear contradiction in the answers: extracurricular training does not support fulfilment of curriculum. 
The wish to participate mainly in subject-related training courses has been the most popular form of self-improvement among all teachers in Estonia throughout the years (Sarv, 2008). It should be mentioned here that the opinion of pedagogues' conflicts with the professional standard of teachers (Professional Standard, 2013), pursuant to which a teacher shall develop, in addition to their professional skills, also the skills of organisation of work, development of study environment, instruction of studies, motivation of students, cooperation, communication and development of a student, analysis and assessment of study process. For some reason it is thought that professional skills/knowledge form the most important part in this list, which needs improvement.

Most continuing education courses, which first and foremost educate a teacher, who can thus raise their qualification and verify competency on the taught speciality, require payment of participation fee. Based on national programme, every year resources intended for specific purpose are assigned to schools in Estonia for continuing education of teachers. This sum is not large, and if a teacher has special interests or they want to participate in several training courses, they shall pay the participation fee themselves. The teachers were asked, if they agree to pay themselves for participation in training courses. $70 \%$ of the teachers answered negatively to this question, while others agreed to pay themselves. As a comment, one pedagogue added that sometimes, when school does not agree to support, they finance the training course themselves. Another comment supported the same idea: "I agree to pay for continuing education courses, if the topic is necessary for me." One interviewed teacher (T3) noted that they do not agree to pay for the courses, as the salary of a teacher is too low. Other two interviewed teachers (T2 and T3) found that maximum sums they would agree to pay for the courses generally remain within the range 50-120 Euros.

The other choices for self-development. Self-improvement does not mean only participation in continuing education courses; it can be done also through other activities. The teachers were asked, which could be the primary and most important method of self-education for them.

The answers showed that the most important form of self-improvement is participation in continuing education courses $(57 \%)$, followed by work with speciality literature $(23 \%)$. The interviewed teachers were asked to specify, how often did they read speciality-related and general educational literature, and which materials specifically. All three pedagogues were mainly interested only in speciality literature, i.e. handicraft periodicals and books. They also visit various web pages.

According to M.T. Brownell successful teachers learn from each other (Brownell et al., 2006). The third major form of self-improvement noted was there consulting with colleagues (19\%). One interviewee (T1) explained that consulting with colleagues provides an opportunity to share and exchange experiences and to compare own results to others. Such approach is more general in Estonia: when problems arise, people prefer to consult each other, instead of searching answers e.g. from scientific literature (Sarv, 2008). This was also confirmed by the answers of another teacher (T3), who also considered important a possibility to visit lessons of colleagues. They found that it is very good and useful method of self-improvement, as it provides opportunities to find new ideas and to compare themselves with colleagues. However, they also said that such option is very difficult to use in real life, because in such case they should find a substitute teacher for themselves, and only few teachers are pleased to accept observers in their lessons. The mentioned teacher proposed an option: handicraft teachers could sometimes conduct organised sample lessons for each other - one teacher would teach, performing their job in traditional way, but instead of students there would be other teachers. This idea is connected to the abovementioned proposal to use practising teachers as lecturers in continuing education courses.

In the research a possibility was offered to the teachers to add comments about continuing education. The feedback was rather active. Among other things it was noted that there are generally few practical training courses, or the courses include themes, which cannot be applied in the study process. Another opinion was that the number of courses is sufficient, but intense work schedule makes participation impossible. Some added comments concerning continuing education courses included specific wish to acquire certain technologies, which again confirms the fact that teachers have very practical attitude towards continuing education courses. 


\section{Conclusions}

The profession of a teacher becomes more complicated: the requirements set to them are increasingly higher, and their work environment is setting constantly more challenges to them. The role of teachers is to be mediators between rapidly changing world and the students entering this world.

From the analysis of the results it can be concluded that handicraft teachers prefer more selfimprovement with practical professional skills than acquisition of methodologies, study styles and methods for passing the knowledge. As it turns out, the handicraft teachers do participate in further leaning, but mostly in form of vocational courses, which is unbalanced. This could have two reasons:

- the handicraft teachers' profession is simultaneously their hobby and they wish to combine available courses with personal interest;

- the average age of the teachers is relatively high, and the teachers are used to participate in practical vocational courses.

\section{Bibliography}

1. Archibald S., Coggshall J.G., Croft A., Goe L. (2011). High-Quality Professional Development for All Teachers. Effectively Allocating Resources. Washington: National Comprehensive Center for Teacher Quality. Retrieved from http://www.gtlcenter.org/sites/default/files/docs/HighQualityProfessionalDevelopment.pdf

2. Arnon S., Reichel N. (2007). Who is the ideal teacher? Am I? Similarity and Difference in Perception of Students of Education Regarding the Qualities of a Good Teacher and of Their Own Qualities as Teachers. Teachers and Teaching: Theory and Practice, 13 (5), 441-464.

3. Beishuizen J.J., Hof E., van Putten C.M., Bouwmeester S., Asscher J.J. (2001). Students' and Teachers' Cognitions about Good Teachers. British Journal of Educational Psychology, 71, 185-201.

4. Brownell M.T., Adams A., Sindelar P., Waldron N., Vanhover S. (2006). Learning from Collaboration: The Role of Teacher Qualities. Council for Exceptional Children, 72 (2), 169-185. Retrieved from http://gsueds2007.pbworks.com/f/teacher+qualities+and+collaboration.pdf

5. Creating Effective Teaching and Learning Environments. First results from TALIS. (2009). OECD. Retrieved from http://www.oecd.org/edu/school/43023606.pdf

6. Gagne R.M., Driscoll M.P. (1988). Essentials of Learning for Instruction. (2 ${ }^{\text {nd }}$ ed.). Upper Saddle River, New Jersey: Prentice Hall.

7. Goe L., Biggers K., Croft A. (2012). Linking Teacher Evaluation to Professional Development: Focusing on Improving Teaching and Learning. USA: National Comprehensive Center for Teacher Quality. Retrieved from https://files.eric.ed.gov/fulltext/ED532775.pdf

8. Fullan M. (2015). The New Meaning of Educational Change. (4th ed.). New York: Teachers College Press.

9. Improving the Quality of Teacher Education. (2007). The Summaries of EU legislation. Retrieved from http://eur-lex.europa.eu/legal-content/EN/TXT/?uri=LEGISSUM\%3Ac11101

10. Kansanen P. (1993). An Outline for a Model of Teachers 'Pedagogical Thinking. In P. Kansanen (Ed.), Discussions on Some Educational Issues IV. Research Report 121. Helsinki: University of Helsinki, 51-65. Retrieved from http://www.helsinki.fi/ pkansane/outline.html

11. Kansanen P. (1995). Teachers' Pedagogical Thinking - What Is It About? In C. Stensmo, L. Isberg (Eds.), Omsorg och engagemang. Uppsala: Uppsala Universitet, 32-45. Retrieved from http://www.helsinki.fi/ pkansane/berglund.html

12. Lifelong Learning is a Crucial Educational Mindset. (2015). Edudemic. Retrieved from www.edudemic.com/lifelong-learning-educational-mindset/

13. Loogma K., Keskula E., Roospold A. (2010). The Transformation of the Teaching Profession in Estonia: Changes in Professionalism. In J. Mikk, M. Veisson, P. Luik (Eds.), Teacher's personality and professionalism. Estonian Studies in Education, 2. Frankfurt am Main: Peter Lang, 11-30.

14. Lofstrom E., Anspal T., Hannula M.S., Poom-Valickis K. (2010). Metaphors About 'The Teacher': Gendered, Discipline Specific and Persistent? In J. Mikk, M. Veisson, P. Luik (Eds.), Teacher's personality and professionalism. Estonian Studies in Education, 2. Frankfurt am Main: Peter Lang, 105-122.

15. Malik A.N., Bashir S. (2015). Good Teacher; Student's Perception about Top Qualities in Health Sciences. The Professional Medical Journal, 22(5), 670-673. 
16. Meijer P.C. (2013). Experienced Teachers' Practical Knowledge as Part of Teacher Education. Eesti Haridusteaduste Ajakiri (Estonian Educational Journal), 1, 8-24.

17. Montalvo G.P., Mansfield E.A., Miller R.B.M. (2007). Liking or Disliking the Teacher: Student Motivation, Engagement and Achievement. Evaluation and Research in Education, 20 (3), 144-158.

18. Mullock B. (2003). What Makes a Good Teacher? The Perceptions of Postgraduate TESOL Students. Prospect, 18(3), 3-24. Retrieved from http://www.ameprc.mq.edu.au/docs/prospect_journal/volume_18_no_3/18_3_1_Mullock.pdf

19. National Curriculum for Basic Schools. (2014). Tallinn: Ministry of Education and Research. Retrieved from https://www.hm.ee/sites/default/files/est_basic_school_nat_cur_2014_general_part_1.pdf

20. Phelan P., Locke-Davidson A., Cao H.T. (1992). Speaking Up: Students' Perspectives on School. The Phi Delta Kappan, 73(9), 695-696, 698-704. Retrieved from https://crceducation.stanford.edu/sites/default/files/speaking-up 0.pdf

21. Professional Standard. Teacher EstQF level 7. (2013). Retrieved from https://www.kutsekoda.ee/fwk/fb/10552237

22. Sarv E.S. (2008). Opetaja ja kool opilase arengu toetajana (Teacher and School as Supporters of Development of Pupils). Tallinn: Tallinna Ulikooli Kirjastus. (in Estonian)

23. Teacher Professionalism. (2012). The Education Union ATL. Retrieved from https://www.atl.org.uk/Images/Teacher\%20professionalism\%20-\%20April\%202012.pdf

24. The Estonian Teacher Education Strategy. (2012). Retrieved from https://issuu.com/eduko/docs/estonian_teacher_education_strategy

25. Thomas L., Beauchamp C. (2007). Learning to Live Well as Teachers in Changing World: Insights into Developing a Professional Identity. Journal of Educational Thought, 41(3), 229-243.

26. Uldhariduse pedagoogide kohta kaiv statistika. (Statistics Pertaining to General Education Pedagogues). (2017). Retrieved from https://www.hm.ee/ehis/statistika.html (in Estonian)

27. Veeber E. (2009). Eesti kasitoo- ja kodundusopetaja professionaalsust mojutavad tegurid (The Influencing Factors of the Estonian Handicraft and Home Economics Teacher's Professionalism). Master's Thesis. Tallinn: Tallinn University. (in Estonian)

28. Wilkins J. (2014). Good Teacher-Student Relationships: Perspectives of Teachers in Urban High Schools. American Secondary Education, 43(1), 52-68. 